\title{
REPRESENTASI KEISLAMAN DALAM GRUP MUSIK SABYAN GAMBUS
}

Islamic Representation of Sabyan Gambus Music Group

\author{
Muhammad Rosyid HW, Siti Lussiyandari
}

\author{
Program Studi Magister Kajian Sastra dan Budaya \\ Fakultas Imu Budaya, Universitas Airlangga \\ Surabaya, Indonesia 60115 \\ Program Studi Magister Kajian Sastra dan Budaya \\ Fakultas Imu Budaya, Universitas Airlangga \\ Surabaya, Indonesia 60115 \\ muhammad.rosyid.husnul-2019@fib.unair.ac.id \\ sitilussiyandari@gmail.com
}

\begin{abstract}
Abstrak: Tujuan dari penelitian ini adalah menjelaskan representasi keislaman dalam kelompok musik Sabyan Gambus. Penelitian ini membahas bagaimana Islam direpresentasikan oleh Sabyan Gambus menggunakan teori Sirkuit Kebudayaan (Circuit of Culture) Stuart Hall (1997). Teori tersebut terdiri dari beberapa aspek, yaitu produksi, konsumsi, regulasi, identitas dan representasi. Penelitian ini menggunakan metode deskriptif kualitatif dalam menjelasakan fenomena kebudayaan. Sebagai data, penelitian ini menggunakan video-video performance Sabyan Gambus di Youtube. Hasil dari penelitian ini, diketahui bahwa kehadiran Sabyan Gambus di Youtube menandai pergeseran penting dari media yang dipakai budaya pop Islam untuk berproduksi. Kemudian, identitas keislaman Sabyan Gambus dapat dilihat melalui sejarah musik gambus di Indonesia, performativitas mereka dan estetika musik mereka. Sabyan juga menunjukkan bahwa identitas islam yang melekat mengalami tarik menarik dengan konteks sosio-budaya Indonesia.
\end{abstract}

Kata Kunci: Representasi, musik Islami, sirkuit kebudayaan

Abstract: The purpose of this study is explained the Islamic representation in the Sabyan Gambus music group. This study discussed how Islam is represented by Sabyan Gambus using the theory of Stuart Hall's Circuit of Culture (1997). The theory consists of several aspects, namely production, consumption, regulation, identity and representation. This research used descriptive qualitative method for explaining cultural phenomena. As data, this study used Sabyan Gambus performance videos on Youtube. The results of this study, it is known that the presence of Sabyan Gambus on Youtube marks an important shift from the media used by Islamic pop culture to produce. Then, the Islamic identity of Sabyan Gambus can be seen through history of gambus music, their performativity, and their music aesthetics. Sabyan also shows that their islamic identity is contested based on indonesian socio-culture context.

Keywords: Representation, Islamic music, circuit of culture

\section{PENDAHULUAN}

Dewasa ini, produk budaya kontemporer dapat meliputi banyak hal yang dapat kita temui sehari-hari seperti film, sastra, musik, televisi, sinetron, iklan, grafiti, slogan, wacana media dan seni rupa. Culture studies menandai perpindahan paradigma ilmu sosial dari positivisme ke fenomenologi; kesadaran bahwa ilmu tidak hanya mengungkap fakta tetapi sesuatu beyond facts sehingga fakta tercipta dan perlunya 
kajian komprehensif yang interdisipliner dalam mengungkap sebuah fenomena. Salah satu produk budaya kontemporer yang sangat populer di Indonesia akhirakhir adalah musik Islam. Saat ini, musik Islami sangat populer di Indonesia. Musik sendiri merupakan karya cipta berupa bunyi atau suara baik yang dihasilkan oleh suara manusia ataupun suara dari alat-alat tertentu. Sedangkan musik Islami adalah seni musik yang bernafaskan Islam. Diketahui bahwa penikmat musik Islami sangat beragam, dari kaum tua hingga kaum muda. Musik Islami yang menjadi populer di semua kalangan ini aktif disebarkan oleh kelompok-kelompok grup musik muda. Grup musik tersebut mudah diterima oleh masyarakat luas karena menyajikan genre yang sesuai selera masyarakat Indonesia. Salah satu, grup musik yang populer, digemari masyarakat luas adalah Sabyan Gambus. Grup ini mulai merilis lagu "Deen Assalam" di Youtube pada 18 Mei 2018. Kemudian, beberapa lagu Sabyan Gambus muncul di Youtube satu demi satu hingga sekarang. Yang paling terakhir adalah "Bismillah" pada 23 Juli 2019. Grup musik ini juga akan merilis lagu baru pada 16 September 2019. Penyanyi Sabyan Gambus adalah Nissa, seorang gadis muda yang mengenakan jilbab. Karya Sabyan Gambus banyak dinikmati diberbagai tempat dan sesuai kebutuhan, seperti pada acara keagamaan (pengajian), pernikahan, dan juga ditampilkan dalam acara hiburan seperti konser maupun acara musik di televisi.

Terdapat beberapa penelitian terdahulu yang mengkaji tentang musik Islami dengan objek yang sama dengan penelitihan ini, yaitu Sabyan Gambus. Yang pertama adalah penelitian dari Muhammad As'ad, dengan judul Sabyan, 'Islamic Musik' and Popular Culture. Penelitian tersebut, menjelaskan mengapa Sabyan menjadi sangat popular. Hasil dari penelitian tersebut adalah Sabyan Gambus menjadi populer karena berbeda dengan musik Gambus versi jadul karena tiga hal; instrumen musik, cara menyanyi (singing style) dan bahasa. Kemudian, penelitian kedua datang dari Molalita, Lestari Rejeki, dan Ida Rosida dengan judul Religious Values in Sabyan's Two Islamic Song Lyrics. Penelitian ini menjelaskan nilai-nilai religius yang terkandung di dalam lirik lagu Sabyan Gambus; Ya Maulana dan Habibal Qolbi dengan menggunakan metode analisis content analysis. Menurut hasil penelitian tersebut, lagu Sabyan menjadi penting karena ia merepresentasikan nilai-nilai Keislaman dan mengandung ajakan (da'wah) kepada kaum muda untuk mengingat Allah dan rasul-Nya. Lagu Sabyan memainkan peran penting dalam proses dakwah. Kemudian, penelitihan Lukman Hadi Setyawan dengan judul Nissa Sabyan dalam Pesan Deen Assalam (Analisis Semiotik) juga mengkaji tentang musik Islami. Tetapi, penelitian tersebut lebih terfokus pada vokalis band Sabyan Gambus saja. Penelitian tersebut, menggunakan metode analisis Semiotik model Charles Sanders Pierce. Serta Analisis verbal dan nonverbal pada video lagu Deen Assalam. Hasil penelitian, menunjukkan bahwa lagu Deen Assalam dapat menyampaikan dan menciptakan rasa damai di masyarakat.

Penelitian keempat, datang dari Birgit Berg dengan judul Musikal Modernity, Islamic Identity, and Arab Aesthetics in Arab-Indonesian Orkes Gambus. Penelitian ini mengkaji orkes Gambus dan perkembangannya di Indonesia. Penelitian ini menemukan bahwa orkes Gambus yang diselenggarakan di Sulawesi Utara, Indonesia dalam konsep acara Halal Bi Halal ternayata tidak hanya dinikmati oleh masyarakat Muslim saja (sebagaimana Gambus diasosiasikan dengan musik muslim). Namun, masyarakat Kristen juga mengikuti acara tersebut dan menjadi sebagian besar (mayoritas) audience yang menikmati musik Gambus dalam acara tersebut. Kemudian, orkes Gambus tidak hanya ditampilkan dalam acara keagamaan saja, namun sekarang juga disajikan 
dalam pernikahan dan kegiatan hiburan lainnya. Saat ini musik Gambus merupakan bagian dari Islamic pop culture yang dinikmati semua orang pada media-media yang tersedia (tv, internet). Peneliti juga menemukan adanya perubahan musik Gambus dari masa ke masa. Seperti perubahan lirik, dimana mereka mengadopsi lirik Arab untuk musik Gambus. Namun, pada saat orde baru, mereka menggunakan bahasa Indonesia karena rezim yang berlaku. Kemudian, pada tahun 1990an, mereka kembali menggunakan bahasa Arab. Adanya modernisasi dan bentuk-bentuk teknologi baru menyebabkan perubahan yang signifikan mendorong ke ranah musik populer Islam modern. Perubahan-perubahan itu memungkinkan orkes Gambus untuk mempertahankan tradisi dan berpartisipasi juga dalam modernitas, sehingga menjadi musik yang Islami dan juga "funki" Musik agar dapat lebih menyatu dengan telinga rakyat Indonesia. Mereka menggabungkan musik Gambus dengan dangdut agar masyarakat non-Arab atau yang tidak familiar dengan bahasa dan lagu Arab dapat ikut serta menikmati musik Gambus.

Penelitian selanjutnya berjudul When Ulama Support A Pop Singer Fatin Sidqiah And Islamic Pop Culture In PostSuharto Indonesia oleh Wahyudi Akmaliah. Tujuan penelitian ini adalah mengkaji kemunculan Fatin Siqdiah sebagai pemenang kontes menyanyi $\mathrm{X}$ Factor dan respon muslim Indonesia tentang budaya populer Islam. Penulis mengungkapkan bahwa fenomena ini adalah proses perjumpaan, dialektika antara agama dan respon logika kapitalis yang menghasilkan "pasar yang berkembang untuk Islam revitalisasi dan gaya hidup". Fatin dianggap sebagai sebuah inspirasi dan panutan bagi pemuda Muslim wanita yang ingin bekerja dan meraih karir mereka tanpa merasa harus meninggalkan penanda identitas Islam mereka, yaitu jilbab.
Berdasarkan penelitian-penelitian terdahulu yang telah disebutkan diatas, dapat disimpulkan bahwa terdapat beberapa perbedaan dengan penelitian ini meskipun terdapat kesamaan dalam objek formal yaitu musik Islami dan Sabyan Gambus. Secara praktis penelitian-penelitian tersebut tidak membahas Sabyan Gambus dengan identitas keislamannya seperti penelitian ini, hanya sebagai sebuah fenomena maupun sebagian kecil representasi dari Sabyan Gambus, padahal Sabyan Gambus dapat diteliti berdasarkan banyak aspek baik kemunculannya, Keislamannya, maupun identitasnya. Kemudian, tujuan dari penelitian ini adalah untuk menjelaskan fenomena kebudayaan Sabyan Gambus melalui pandangan representasi Stuart Hall. Penelitian ini membahas secara keseluruhan kelompok musik Sabyan Gambus, bagaimana Islam direpresentasikan oleh Sabyan Gambus menggunakan teori Sirkuit Kebudayaan (Circuit of Culture) oleh Stuart Hall. Teori ini dicetuskan oleh Hall pada tahun 1983 di Inggris, utamanya University of Birmingham, tempat dimana Hall bekerja dan mengajar. Konsep sirkuit budaya dicetuskan oleh Stuart Hall (1997) dimana terdiri dari beberapa aspek, yaitu produksi, konsumsi, regulasi, identitas dan representasi. Menurut Hall, representasi merupakan focus utama dalam produksi budaya dan inti dari circuit of culture. Dalam sirkuit budaya, makna dapat diperoleh dari aspek yang berbeda-beda, yang kemudian makna lah yang memberikan rasa tentang identitas. Penelitian ini juga untuk mencari tahu bagaimana Sabyan Gambus yang dikategorikan sebagai musik 'Islami'. Secara praktis untuk mengetahui mengapa Sabyan Gambus mampu mencuri perhatian dan menjadi idola masyarakat menengah muslim dalam selera musik Islami mereka. Data dari penelitian ini didapat dari videovideo yang Sabyan Gambus upload di Youtube. 


\section{METODE}

Penelitian ini menggunakan metode deskriptif kualitatif dalam menjelasakan fenomena kebudayaanmusikIslami yang dibawakan grup musik Sabyan Gambus. Dalam penelitian ini, penulis menggunakan videovideo performance Sabyan Gambus di Youtube sebagai data penelitian. Penulis mencari bagaimana pendapat, komentar, ataupun kritik dari para ahli serta masyarakat tentang Sabyan Gambus itu sendiri, mengenai kemunculan Sabyan Gambus dan bagaimana mereka menginterpretasikannya dengan nilai-nilai Keislaman yang ada di Indonesia. Melalui teori Circuit of Culture oleh Stuart Hall penulis melihat Sabyan Gambus sebagai sebuah fenomena kebudayaan dengan mencari tahu dan menganalisis Sabyan Gambus dalam proses produksi dan konsumsinnya sehingga identitas dan representasi Sabyan Gambus terbentuk. Kemudian, penulis juga mencermati jalinan regulasi yang mengiringinya.

\section{HASIL DAN PEMBAHASAN}

\section{Sabyan Gambus dan Media Baru}

Sabyan Gambus adalah sebuah grup musik gambus yang beranggotakan 5 remaja dan terbentuk pada tahun 2015 . Personelnya terdiri dari Khoirunnisa alias Nissa (vokalis), Anisa Rahman (vokalis dua), Ayus (kibor), Kamal (pemain gendang), Tebe (pemain biola) dan Sofwan (MC). Grup musik islami ini tiba-tiba menjadi viral dengan kemunculannya yang membawakan shalawat baik dengan menyanyikan ulang (cover) ataupun menyanyikan karya baru dengan aransemen musik kekinian. Terbentuknya grup musik Sabyan Gambus ini berawal dari sebuah latihan band bersama saja. Saat itu, mereka belum mengambil job untuk tampil di depan umum. Kemudian, setelah 6 bulan mereka mendapatkan banyak kesempatan untuk tampil di panggung-panggung dan mendapatkan Khoirunnissa (Nissa) sebagai vokalis tidak tetap yang kemudian malah menjadi 'ikon' Sabyan Gambus.

Yang menarik adalah bahwa melalui kanal media baru yaitu Youtube, Sabyan Gambus memperoleh kepopulerannya. Mereka menggunakan platform Youtube untuk mengunggah video hasil rekaman mereka dalam menyanyikan lagu-lagu Islami. Mereka memiliki dua akun Youtube yang aktif, yaitu Official Sabyan Gambus dan Sabyan Channel. Kedua akun ini telah dinikmati oleh para pendengar musik dengan jumlah yang sangat fantastis. Official Sabyan Gambus kini telah di-subscribe oleh enam juta penonton sementara Sabyan Channel, akun youtube Sabyang Gambus yang lain, telah memiliki 2 juta lebih subscriber. Berikut rincian para penikmat dan pendengar Sabyan Gambus di Youtube ${ }^{1}$ :

\footnotetext{
${ }^{1}$ Diakses pada 23 November 2019
} 
Daftar Para Penikmat Sabyan Gambus di akun Official Sabyan Gambus

\begin{tabular}{|l|l|l|r|r|}
\hline No. & Judul Lagu & Tanggal Rilis & Jumlah views & Jumlah Likes \\
\hline 1 & Qomarun & 21 Agustus 2017 & 36.493 .586 & $204 \mathrm{~K}$ \\
\hline 2 & Ahmad Ya Habibi & 28 Agustus 2017 & 32.805 .036 & $134 \mathrm{~K}$ \\
\hline 3 & Ya Habibal Qolbi & 25 December 2017 & 323.237 .751 & $1.7 \mathrm{M}$ \\
\hline 4 & Rohman Ya Rohman & 25 Januari 2018 & 141.042 .342 & $570 \mathrm{~K}$ \\
\hline 5 & Ya 'Asyiqol Mustofa & 6 April 2018 & 226.791 .870 & $226 \mathrm{M}$ \\
\hline 6 & Ya Jamalu & 11 May 2018 & 109.555 .825 & $109 \mathrm{M}$ \\
\hline 7 & Deen Assalam & 17 May 2018 & 256.125 .292 & $1.9 \mathrm{M}$ \\
\hline 8 & Ya Maulana & 23 May 2018 & 292.144 .773 & $1.4 \mathrm{M}$ \\
\hline 9 & Allahumma Labbaik & 2 November 2018 & 39.097 .216 & $39 \mathrm{M}$ \\
\hline 10 & El-Oum & 22 Desember 2018 & 18.111 .180 & $18 \mathrm{M}$ \\
\hline 11 & Thank to Allah & 12 Januari 2019 & 22.640 .188 & $22 \mathrm{M}$ \\
\hline 12 & Bismillah & 23 Juli 2019 & 3.836 .198 & $3.8 \mathrm{M}$ \\
\hline
\end{tabular}

Daftar Para Penikmat Sabyan Gambus di akun Sabyan Channel

\begin{tabular}{|l|l|l|r|l|}
\hline No. & Judul Lagu & Tanggal Rilis & \multicolumn{1}{|l|}{ Viewers } & Jumlah Likes \\
\hline 1. & Idul Fitri & 30 May 2019 & 10.141 .456 & $220 \mathrm{~K}$ \\
\hline 2. & Ya Allah Biha & 16 September 2019 & 2.377 .997 & $78 \mathrm{~K}$ \\
\hline 3. & Alfa Salam & 22 November 2019 & 87.043 & $13 \mathrm{~K}$ \\
\hline
\end{tabular}

Penggunaan youtube sebagai media untuk merilis dan memproduksi lagu adalah hal baru dalam belantika musik Indonesia, utamanya musik islam. Hal ini mendorong musik gambus untuk mendapatkan penikmat yang lebih luas daripada masa sebelumnya sehingga terjadi proses populerisasi musik gambus yang dilihat dari dua hal.

Pertama, Sabyan Gambus memangkas sekat-sekat agama dalam hal penikmatan musik gambus. Melalui media Youtube yang demokratis, Sabyan Gambus menyajikan musik yang membuka kemungkinan untuk dinikmati siapapun tanpa pandang latar belakang agama.

Dahulu, musik Gambus hanya dinikmati oleh kaum muslim saja, yang kental dengan adat istiadat islam dan seluruh peraturan-peraturannya (dimana terdapat kepercayaan bagi pendengar musik islami akan mendapat keberkahan atas-Nya).

Namun, terjadi pergeseran identitas atas musik Gambus itu sendiri yang bergantung pada setiap daerah yang menyelenggarakannya. Musik Gambus yang terasosiasi dengan keislaman dan berasal dari tanah suci, ternyata juga dinikmati oleh kaum nonmuslim. Dalam penelitian Birgit Berg, Musik Gambus memang ditampilkan dalam acara keagamaan, yaitu 'halal-bihalal'. Musik Gambus dipersembahkan sebagai pembuka acara yang terasosiasi dengan muslim tersebut. Namun, setelah diketahui, peserta dan penonton acara tersebut bukan hanya masyarakat muslim saja, melainkan nonmuslim juga mengikutinya. Acara halal bi halal di Sulawesi Utara yang diselingi orkes Gambus tersebut juga banyak dinikmati juga oleh kaum Nasrani. Acara itu sendiri sebenarnya merupakan acara bermaafmaafan yang diselenggarakan umat muslim setelah hari raya idul fitri. Acara tersebut dihadiri oleh para masingmasing pemuka agama yang memberikan ceramah sebagai bentuk syukur atas kedamaian yang mereka dapatkan. Keikutsertaan warga nonmuslim dalam acara tersebut menunjukkan keberagaman beragama yang damai dengan sikap toleransi yang tinggi. Hal ini dapat menjadi sebuah benang merah, bahwa musik Gambus tidak hanya terasosiasi dengan islam saja. Dalam beberapa konteks daerah tertentu 
seperti di Sulawesi Utara tersebut, agama Kristen yang menjadi mayoritas pun turut menikmati musik Gambus. Musik Gambus dapat diterima masyarakat di daerah tersebut karena mereka menggabungkan unsur kebudayaan tradisional di dalamnya.

Sementara itu, Sabyan Gambus membawa musik gambus dari penikmat lokal ke penikmat global karena siapapun dengan latar keagamaan apapun dapat mengakses musik-musik Sabyan Gambus di Youtube. Beberapa tangkap layar membuktikan bahwa banyak kalangan nonmuslim yang juga menikmati musik gambus ala Sabyan.
Kebanyakan dari mereka memberikan komentar bahwa meskipun mereka nonmuslim, tapi mereka sangat tersentuh dan menyukai lagu Sabyan Gambus. Meskipun juga mereka tidak mengetahui makna dari lagu-lagu tersebut tetapi mereka merasa damai dan tenang saat mendengarkannya. Sebenarnya, mereka sadar bahwa musik tersebut adala musik islami yang dinyanyikan dan diperdengarkan oleh kaum muslim, namun tidak ada penyangkalan bahwa mereka menyukai hal-hal yang berbau modern dan kontemporer.

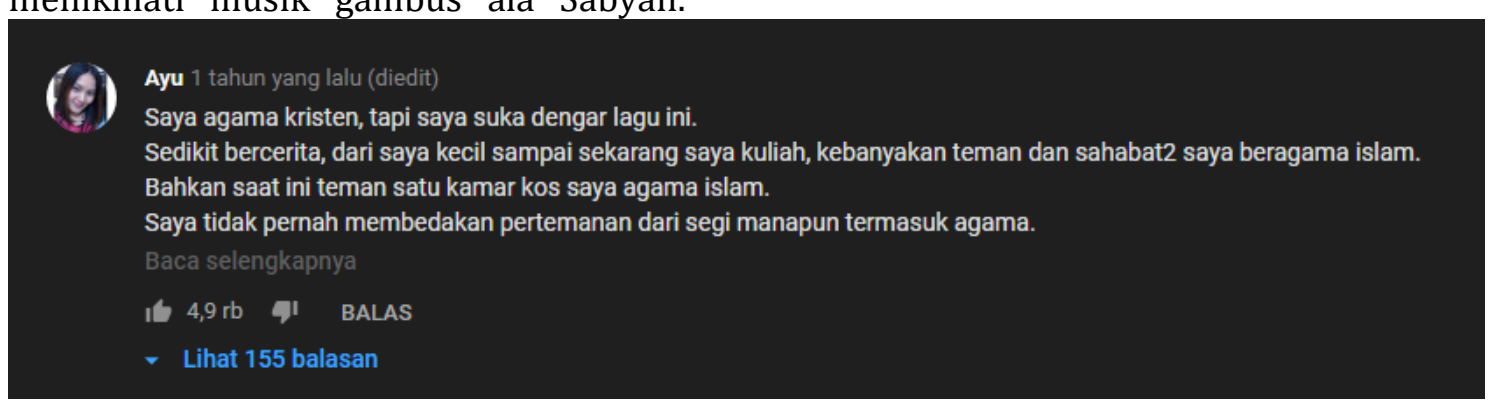

syifa fachriah 4 days ago

Lagu ini salah satu penyemangat Dan pengingat Ku kepada Allah ketika melalui masa2 sulit kemarin. Terimaksih sabyan. Barakallah :)

Kedua, melalui Youtube pula, musik Sabyan Gambus juga menembus batas-batas tempat karena Sabyan Gambus dapat dinikmati dan didengarkan dari wilayah dan negara manapun. Al Hamed dan Natesh, mahasiswa internasional asal Timur Tengah yang sangat menyukai Sabyan Gambus dan lagu-lagunya, merupakan hal yang baru dan menarik. ${ }^{2}$ Mereka menyukai produk Sabyan Gambus tersebut bukan hanya terdapat kesamaan bahasa universal Timur tengah yang mereka pelajari dan gunakan, tetapi mereka juga terpikat akan bagaimana Sabyan Gambus menyajikannya sebagai bentuk budaya kontemporer. Di negara asal mereka, lagu-lagu seperti yang ditampilkan oleh Sabyan Gambus

\footnotetext{
${ }^{2}$ Interview tanggal 10 November 2019
}

biasanya terasosiasi dengan "musik tradisional" yang menggunakan alat musik tradisional serta ditampilkan dalam acara-acara kebudayaan dan keagamaan. Namun, di Indonesia, mereka melihat sesuatu yang baru, dimana lagu yang erat kaitannya dengan keagamaan tersebut, disajikan dalam bentuk kekinian yang sesuai dengan style muslim muda modern yang menjadikannya sebuah hiburan yang positif dan menarik.

Kehadiran Sabyan Gambus di Youtube menandai pergeseran penting dari media yang dipakai budaya pop islam untuk berproduksi. Hal ini berbeda dengan masa sebelumnya dimana budaya pop islam menjamur di televisi dan radio. ${ }^{3}$

\footnotetext{
${ }^{3}$ Noorhaidi Hasan, "The Making of Public Islam; Piety, Agency and Commodification on
} 
Implikasi media baru ini adalah Sabyan Gambus sebagai budaya pop islam dapat dinikmati secara lebih luas dan berhasil menembus batas-batas perbedaan agama dan sekat-sekat teritorial.

\section{Sabyan Gambus dan Representasi Islam}

Sabyan Gambus telah menjadi idola baru bagi para penikmat dan pendengar musik tanah air. Grup musik ini telah berhasil menggunakan munculnya media baru, Youtube, sebagai wahana untuk memperkenalkan karya-karya mereka. Dengan mengusung musik gambus dan vokalis yang berkerudung, mereka dianggap mengisi dahaga umat muslim di Indonesia dalam hal menikmati musik. Sabyan Gambus dilekatkan sebagai bagian dari musik islam dan merepresentasikan keislaman. Pertanyaannya kemudian, mengapa Sabyan Gambus dianggap demikian? Dengan mengamati fenomena kebudayaan secara seksama, penulis menemukan Sabyan Gambus merepresentasikan keislaman disebabkan oleh beberapa faktor, yaitu sejarah musik gambus di Indonesia, penampilan Sabyan Gambus dan estetika musik yang diusung oleh Sabyan Gambus. Saat ini, Sabyan Gambus merupakan grup music yang banyak digemari oleh masyarakat Indonesia. Dalam hal bermusik, kelompok ini mengusung tema Islami. Hal-hal yang terkait dengan agama Islam, melekat erat pada citra grup ini. Hal ini dapat ditunjukkan melalui tanda-tanda yang terdapat dalam komponen grup musik tersebut serta musik itu sendiri, diantaranya adalah model musik, lirik dan penampilan.

Sesuai dengan namanya, kelompok music Sabyan Gambus mendeklarasikan kelompok mereka membawakan music beraliran gambus. Gambus merupakan suatu aliran music yang lebih luas digunakan dalam music religious islam (Mukarram, 2010). Sesuai dengan pendapat ini, Sabyan Gambus juga merupakan aliran music yang memiliki "identitas" Islam didalamnya. Kemudian, instrumen pendukung tambahan dalam ansambel musik gambus sering kali menggunakan seperangkat rebana atau marwas, gendang kecil dengan kedua sisinya tertutup membran (jenis kulit) yang dipukul dengan tangan (hand drum) (Mukarram, 2010). Hal ini juga diperkuat oleh pendapat Berg bahwa mula-mula musik gambus diadopsi dari budaya Melayu untuk mengiringi pembacaan pantun di Sumatra dan Pulau Riau dimana identitas Melayu memiliki ikatan yang kuat dengan Islam, baik secara historis maupun kultural (Berg, 2011). Ia juga membuktikan bahwa istrumen gambus pada awalnya dimainkan dan dinikmati oleh komunitas ArabIndonesia yang tentunya identik dengan agama Islam. Berdasarkan hal tersebut terdapat kontradiksi antara konsep awal music gambus dengan konsep music gambus yang dipopulerkan oleh Sabyan. Hal ini mengacu pada tidak adanya eksistensi alat music tradisional khas music gambus seperti rebana dan gendang yang digunakan Sabyan dalam aransemen musiknya. Alih-alih menggunakan alat music tradisional, Sabyan menggunakan alat music modern seperti gitar, keyboard, drum, biola dan sebagainya seperti pada gambang dibawah ini: the landscape of the Indonesian Public Sphere", Contemporary Islam, vol. 3, no. 3 (2009) p. 245 


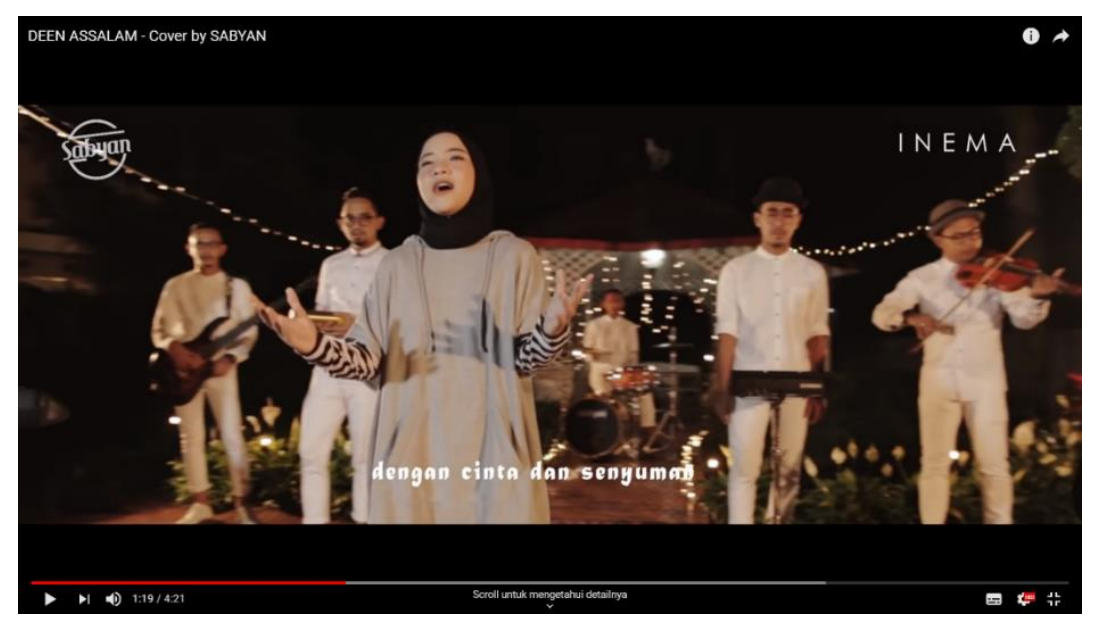

Diakses pada Senin, 16 Desember 2019

Berdasarkan hal tersebut, terdapat perubahan konsep music gambus yang terjadi pada masa kini. Perubahan tersebut dapat diidentifikasi sebagai bentuk usaha Sabyan dalam memberikan nuansa baru pada music gambus. Seperti yang diungkapan Berg pada bukunya yang berjudul Islam and Popular Culture in Indonesia and Malaysia, bahwa music gambus diperdengarkan di acara-acara penting seperti pernikahan dan acara keagamaan. Sama halnya seperti Sabyan, music mereka juga diperdengarkan pada acara-acara penting yang sama. Namun, karena konteks budaya yang sudah berubah dari zaman ke zaman, sehingga menimbulkan pergeseran alat music yang digunakan menjadi lebih modern. Meskipun terdapat perbedaan alat music yang "tampak digunakan", tidak menutup kemungkinan bahwa alat-alat music tradisional seperti rebana dan gendang tersebut dapat di-cover oleh alat-alat musik modern. Seperti yang kita tahu bahwa alat music modern dapat menghasilkan suara-suara alat tradisional.

Kemudian, jika dilihat dari histori atau asal mula kemunculan music gambus, pada awalnya, musik gambus di Indonesia berasal dari Negeri Arab. Pada abad ke-19 orang Persia dan Arab melakukan perdagangan di Kepulauan

Rohman ya Rohman

Wahai yang maha pengasih

Saidni ya Rohman
Melayu. Mereka membawa instrumen ini di kapal kapal mereka untuk menjadi hiburan pribadi pada perjalanan laut yang Panjang. Kemudian, musik hiburan tersebut diduga menyerupai musik Gambus yang telah diperkenalkan oleh para pedagang Arab dan Persia tersebut ketika berdagang di sepanjang Kepulauan Melayu (N \& Zapin, 2004). Masuknya Gambus di Indonesia, juga berkaitan dengan masuknya Islam ke daerah-daerah di Indonesia sehingga musiknya terasosiasi dengan music masing-masing daerah atau bahkan music modern. Sehingga, dapat ditarik suatu benang merah bahwa music gambus berkaitan dengan agama Islam serta Sabyan gambus merupakan kelompok music yang beridentitaskan agama tersebut.

Yang kedua, identitas keislaman Sabyan gambus dapat dilihat dari lirik lagu-lagu yang mereka bawakan. Sabyan gambus memiliki dua tipe lagu yang mereka unggah di akun Youtube mereka, yang pertama adalah cover atau menyanyikan ulang, kemudian yang kedua adalah lagu ciptaan mereka sendiri. Berikut merupakan penggalan lirik lagu yang dinyanyikan ulang oleh Sabyan Gambus berjudul Rohman ya Rohman yang berarti Wahai Yang Maha Pengasih:

Bantulah aku Yang Maha Pengasih Isyroh shodri Quran

Lapangkan dadaku dengan Quran 
Imla, qolbi Quran

Penuhi hatiku dengan Quran

Washlih hayati Quran

Sirami rohaniku dengan Quran

Lillah lillah yahfu amali lillah

Karena Allah, begitu mendalam

keinginanku karena Allah

Wa lihifdhi kitabillah

Bisakah aku mempelajarinya

Min awwali bismillah

Dimulai dengan bismillah

Lilkhotmi wa lirridlwan

Hingga khatam dan meraih keridhoan-Mu

Kemudian, berikut merupakan penggalan lirik dari lagu yang diciptakan Sabyan Gambus sendiri, dengan judul Syukron Lillah:

Kusadari semua yang kuingin bukan yang terbaik

Yang Kau beri tak selalu jadi keinginan hati

Ampuni salahku menilaiMu, salahku telh jauh dariMu

Alhamdulillah wasyukurillah

Tak pantas ku mengeluh

Kau telah beri ku segalanya

Berdasarkan lirik pada kedua lagu tersebut, dapat disimpulkan bahwa Sabyan Gambus memang melekatkan dirinya dengan identitas agama Islam. Dalam lagu cover yang berjudul Rohman ya Rohman, terlihat mereka melafalkannya dengan Bahasa Arab

\section{Sabyan Gambus dan Kontestasi Identitas Islam}

Fenomena kehadiran Sabyan Gambus dalam budaya pop Indonesia tidak hanya menyajikan bahwa mereka merepresentasikan keislaman an sich, tetapi juga grup musik ini menjadi contoh bagaimana bentuk islam dalam budaya populer serta hubungan tarik menarik antara islam dengan konteks sosio-budaya di Indonesia. Sabyan Gambus menegaskan bahwa islam selalu daripada menerjemahkannya dalam Bahasa Indonesia atau Bahasa Inggris. Hal ini didasarakan bahwa memang lagu tersebut dinyanyikan dalam Bahasa Arab oleh penyanyi aslinya. Meskipun pendapat tersebut dapat dipatahkan dengan banyaknya Negara yang menggunakan Bahasa Arab namun tidak semua penduduknya bergama Islam, namun dalam praktiknya Sabyan menekankan beberapa hal "keislaman" dalam liriknya, yaitu seperti kata Allah yang merupakan Tuhan bagi umat Islam, serta Quran yang merupakan kitab suci Muslim. Sehingga dapat disimpulkan bahwa, salah satu factor yang menunjukkan identitas Islam Sabyan Gambus lirik lagu yang mereka bawakan.

Kemudian, identitas keislaman juga dapat dilihat dari cara mereka berpakaian. Dalam hal dressing ini, hal yang paling mencolok terlihat pada sang vokalis sebagai representasi grup. Nissa, sebagai seorang perempuan Muslim, selalu menggunakan jilbab. Meskipun banyak pendapat yang mematahkan bahwa penggunaan jilbab bukan berarti seorang Muslim, namun hal tersebut tidak berlaku di Indonesia. Dalam acara apapun, Nissa selalu tampil mengenakan jilbab dan pakaian yang menutup aurat. Hal ini selain dua aspek diatas, juga dapat membuktikan identitas keislaman Sabyan Gambus sebagai kelompok music beraliran Islam. Tidak pernah ada satupun penampilan Nissa, sang vokalis, yang tidak memakai jilbab, baik dalam penampilan on-air maupun off-air.

mampu beradaptasi dengan geliat zaman dan modernitas. Hal ini terbukti dengan eksistensi Nissa, vokalis Sabyan Gambus dan musik karya Sabyan Gambus.

Citra bahwa perempuan berjilbab adalah ketinggalan zaman seakan lenyap dengan menilik sosok Nissa. Nissa Sabyan menjadi contoh tentang gambaran seorang wanita remaja yang tetap menjaga dirinya sebagai seorang muslimah sekaligus penyanyi yang modis, fashionable dan modern. Bahwa gambus, sebagai representasi musik 
islam, yang ia bawakan tidak menghalanginya untuk mengenakan kostum yang kekinian. Nissa sendiri mengakui bahwa penyanyi gambus pada umumnya itu biasanya mengenakan high-heels, wedges, pakai gamis dengan warna putih dan pink. Namun, karena Nissa nampak sangat dewasa dengan memakai gamis, Ayus (keyboardist Sabyan Gambus) menyarankannya untuk menyanyi dengan baju casual agar terlihat seperti remaja pada umumnya. Akhirnya, Nissa pun mulai memakai sepatu sneaker dan jaket kekinian seperti hoodie tanpa meninggalkan unsur keislaman yaitu menutup aurat dan pakaian yang tidak ketat. Bahkan, respon publik terhadap cara berpakaian Nissa sangatlah mendukung hingga kemudian banyak anak muda yang mulai menyukai Sabyan Gambus. ${ }^{4}$ Jilbab yang dipakai Nissa saat bernyanyi di ruang publik pun nyaris tanpa perdebatan sama sekali. Nissa dan Sabyan Gambus diterima di banyak pondok pesantren, masjid-masjid juga sekolah Muhammadiyah. Hal ini membuktikan bahwa akomodasi islam dan gaya modern dalam pakaian dan jilbab yang dikenakan oleh Nissa diterima oleh kalangan muslim.

Fenomena Nissa Sabyan adalah tanda penegasan penerimaan seorang penyanyi perempuan yang berjilbab dan tampil secara publik di Indonesia. Ini adalah hasil kontestasi dan perdebatan panjang antara hukum islam dan budaya di Indonesia. Dahulu, wanita dilarang bernyanyi di tempat umum karena suaranya dianggap sebagai hal yang harus ditutup dan tidak boleh ditampilkan secara publik (aurat) karena wanita dianggap sebagai makhluk lemah yang harus dijaga dari hasrat laki-laki yang melihat atau mendengarkan suara mereka. ${ }^{5}$ Namun, sekarang penampilan

\footnotetext{
${ }^{4}$ https://youtu.be/5B4gejBkTxk (Talkshow Sabyan Gambus di acara Alvin \& Friend) diakses pada 23 November 2019

${ }^{5}$ Bart Barenderg, "The Art of No-Seduction: Muslim Boy-Band Music in Southeast Asia and The Fear of Female Voice", IIAS
}

penyanyi perempuan di acara publik semakin diterima. Bahkan, beberapa tahun silam, seorang kiai yang juga anggota MUI (Majelis Ulama' Indonesia) memberikan pernyataan publik agar masyarakat muslim Indonesia mendukung Fatin Shidqia sebagai penyanyi perempuan yang berjilbab dalam kontes Indonesia X Factor. ${ }^{6}$

Dalam hal bermusik, Sabyan Gambus juga membawa musik gambus di Indonesia ke arah yang lebih populer. Dahulu, gambus dianggap sebagai musik tradisional dan hanya bisa dinikmati oleh kalangan tertentu yaitu komunitas Indonesia-Arab. As'ad (2018) menyebutkan bahwa dalam gambus klasik, instrumen musiknya terdiri dari kecapi gambus, keyboard dan drum klasik seperti kaprak dan tarbuka. Sedangkan, instrumen yang biasa dipakai Sabyan Gambus berbeda. Sabyan bahkan dengan berani meninggalkan kecapi gambus dan mereka mempergunakan alat musik modern seperti keyboard, biola, darbuka dan gitar. Praktis, hanya alat musik darbuka yang menjadi satusatunya penanda bahwa musik mereka adalah gambus. Namun, dengan komposisi alat musik seperti ini, gambus menjadi terkesan modern, tidak tradisional dan tidak ketinggalan zaman. Seperti yang ditulis oleh Birgit Berg (2011: 169) bahwa Orkes gambus music is a site where Arab Indonesian performers put tradition and modernity, forces often thought to contradict one another, into dialogue through the use of global flows and technology.

Gadis berjilbab yang stylish dan balutan musik modern dalam

Newsletter (2006),

https://www.iias.nl/sites/default/files/IIAS NL40 10.pdf, diakses pada 23 November 2019

${ }^{6}$ Wahyudi Akmaliyah "When Ulama Support a Pop Singer: Fatin Sidqiah and Islamic Pop Culture in Post-Suharto Indonesia", AlJamiah, Vol. 52, No. 2 (2014) https://doi.org/10.14421/ajis.2014.522.351$\underline{373}$ 
menyanyikan selawat menjadi hal yang paling menonjol di lagu-lagu cover awal Sabyan Gambus di Youtube. Penulis berargumen bahwa kedua kesan inilah yang telah menarik banyak penonton (viewer) yang kemudian membawa Sabyan Gambus meraih tangga popularitas. Citra modern yang melekat ke Sabyan Gambus juga membawa implikasi tersendiri dalam citra identitas mereka; yaitu kelas menengah muslim. Hal ini terbukti bahwa untuk mengesankan modern dan tak ketinggalan zaman, video-video clip mereka juga menegaskan kelas sosial mereka. Mobil, rumah bertingkat dan kemewahan interior rumah menunjukkan bahwa citra Sabyan Gambus adalah citra kelas menengah muslim. ${ }^{7}$

Apa yang ditampilkan oleh Sabyan Gambus menyedot atensi kaum menengah muslim dalam menampilkan identitas dan keislamannya melalui konsumsinya terhadap musik Sabyan Gambus. Wasisto Jati (2015:159) menyebutkan bahwa melalui konsumsi dalam konteks pemenuhan kesenangan (leisure) dan kepuasan (pleasure) menjadi misi utama yang dicari oleh Muslim Kelas Menengah. Seperti halnya kemunculan bank-bank syariah, film dan sinetron islami, media masa islam, hingga lembaga filantropi islam menandai pola-pola konsumsi masyarakat muslim menengah ini. ${ }^{8} \mathrm{Hal}$ ini juga berbanding lurus dengan bagaimana musik Sabyan Gambus dikonsumsi. Sabyan mengisi ruang

\footnotetext{
${ }^{7}$ Lihat video lagu "Syukron Lillah", "Idul Fitri", "La Tabki Ya Shoghiri", "Ya Jamalu” di Youtube "Sabyan Ofiicial"

8 Lihat Heryanto, Ariel. Identitas dan Kenikmatan: Politik Budaya Layar Indonesia. Jakarta,: Gramedia, 2015 dan Noorhaidi Hasan, "The Making of Public Islam; Piety, Agency and Commodification on the landscape of the Indonesian Public Sphere", Contemporary Islam, vol. 3, no. 3 (2009) p. 245
}

kosong akan konsumsi musik bagi kelompok masyarakat ini. Maka tak heran jika selawat dan musik gambus mereka banyak diperdengarkan di tempat-tempat yang menjadi representasi kelas menengah yaitu di mall, pusat-pusat perbelanjaan, acara mewah pernikahan dan mobil-mobil.

Ketenaran Sabyan Gambus yang semakin banyak digemari orang menjadi daya pikat tersendiri. Popularitas Sabyan menjadi magnet untuk menarik banyak orang ke dalam kelompok masyarakat tertentu yang salah satunya adalah organisasi kemasyarakatan. Pada mulanya adalah sebuah video viral dimana Nissa Sabyan bersama ketua IPPNU Rekanita Puti Hasni yang menyatakan bahwa Nissa bersedia menjadi anggota Ikatan Pelajar Putri Nahdlatul Ulama' (IPPNU) ${ }^{9}$. Lalu, kemudian foto dimana Nissa Sabyan memakai baju seragam IPPNU juga beredar luas di media sosial. Meskipun video pernyataan Nissa tersebut adalah nyata dan foto Nissa berseragam $\mathrm{Nu}$ kemungkinan hoax, Sabyan Gambus secara resmi tidak pernah menampik kalau mereka dilekatkan kepada ormas terbesar di Indonesia ini. Namun, di sisi lain, mereka juga tidak pernah menyatakan di depan publik bahwa mereka adalah bagian dari NU.

Beberapa penampilan mereka malah semakin menegaskan bahwa mereka bersedia untuk dicitrakan sebagai pengikut NU. Karena pada suatu ketika, Sabyan Gambus pernah menyanyikan lagu "Ya Lal Wathan" yang menjadi salah satu lagu kebanggan NU10. Sabyan Gambus juga pernah menjadi juri dari lomba selawat yang diadakan oleh

\footnotetext{
9

https://www.youtube.com/watch?v=aCYSOI oof s (Nissa Sabyan bergabung ke IPPNU)

${ }^{10}$ https://youtu.be/CdoMEJNd2Nc (Nissa Sabyan menyanyikan lagu "Ya Lal Wathan" di Tegal) dan

https://www.nu.or.id/post/read/100543/senan dung-cinta-shalawat-nu-tegal-hadirkan-sabyangambus-
} 
Pengurus Pusat Muslimat NU11. Musik Sabyan Gambus yang pada awalnya hanya diasosiakan secara umum kepada islam, namun kemudian citra ormas Nahdlatul Ulama' melekat pada mereka. Ditambah lagi, mereka mengusung selawat kepada nabi yang juga menjadi ajaran yang sering didengungkan oleh NU.

Kepopuleran Sabyan Gambus juga menariknya ke dalam pusaran politik. Massa dan penggemar yang sangat luar biasa banyak membuat para politisi mendekatinya demi kepentingan politik. Diantaranya adalah Sandiaga Uno ${ }^{12}$ dan Rahayu Saraswati ${ }^{13}$, dua politisi Gerindra. Meskipun Saraswati menyatakan bahwa mengajak Sabyan adalah untuk mengkampanyekan agar para milineal tidak golput, tapi sudah sangat jelas bahwa kampanye itu adalah kampanye partai Gerindra untuk mendukung pasangan calon presiden tertentu. Pada perhelatan pemilu 2019, Sabyan Gambus juga kerapkali tampil dalam kampanye calon presiden dan wakil presiden nomer urut 02; PrabowoSandi ${ }^{14}$. Di sisi lain, tidak pernah ada satu pun bukti bahwa Sabyan Gambus ikut dalam kampanye dari calon presiden dan

11

https://www.youtube.com/watch?v=xGldOfmz reE (Gelar Lomba Selawat, Muslimat Gandeng Sabyang Gambus) dan

https://www.nu.or.id/post/read/98556/adakan -lomba-shalawat-daring-muslimat-nu-gandengsabyan-gambus

${ }^{13}$ https://news.detik.com/berita/d4500107/gandeng-nissa-sabyan-saraswati$\frac{\text { dorong-milenial-tak-golput }}{14}$

https://regional.kompas.com/read/2019/03/25 21522401/diguyur-hujan-grup-sabyangambus-hibur-pendukung-prabowo-sandiaga, https://pemilu.antaranews.com/berita/828504 /rhoma-dan-nissa-sabyan-semarakkankampanye-prabowo-sandi-di-tangerang, https://www.cnnindonesia.com/nasional/2019 0308161953-32-375619/prabowo-tolakbernyanyi-selawat-dengan-nisa-sabyan-dibandung wakil presiden kubu satunya. Hal ini menegaskan pilihan politik dari Sabyan Gambus.

Akhirnya, Sabyan Gambus dengan musik-musiknya secara jelas menunjukkan representasi keislaman, namun ia juga melalui tahap tarik menarik dengan konteks sosial budaya yang mengiringinya seperti modernitas, kelas menengah muslim, organisasi masyarakat dan pilihan politik.

\section{KESIMPULAN}

Kemunculan Sabyan Gambus dalam belantika musik islam di Indonesia menjadi hal yang menarik karena mereka mempergunakan Youtube untuk memproduksi karya-karyanya. Sebagai bagian dari perkembangan teknologi, Youtube telah menjadi media baru bagi kemunculan grup musik yang bercitra islam di Indonesia. Hal ini menjadi penanda penting dari bergesernya media dimana budaya pop islam berproduksi; dari radio dan televisi ke media sosial. Sabyan Gambus sangatlah identik dengan islam karena citra keislamannya yang tercermin dan terepresentasikan dari tiga hal yaitu sejarah musik gambus di Indonesia, bagaimana mereka tampil dan estetika musik mereka. Meskipun begitu, Sabyan Gambus juga menjadi titik penting dari pelbagai macam kontestasi identitas yang berlangsung dalam budaya pop islam di Indonesia. Mulai dari tarik menarik hubungan islam dan modernitas, pola konsumsi masyarakat menengah muslim, kontestasi antar organisasi masyarakat dalam menarik massa, serta persaingan politik dalam perebutan kursi kekuasaan. 


\section{REFERENSI}

Akmaliah, Wahyudi. "When Ulama Support a Pop Singer: Fatin Sidqiah and Islamic Pop Culture in PostSuharto Indonesia", Al-Jamiah, Vol. 52, No. 2 (2014).

As'ad, Muhammad. "Sabyan, 'islamic music' and popular culture", The Jakarta Post, 29 Juni 2018.

Barenderg, Bart. "The Art of NoSeduction: Muslim Boy-Band Music in Southeast Asia and The Fear of Female Voice", IIAS Newsletter (2006),

Berg, Birgit. 2011. "Musical Modernity, Islamic Identity, and Arab aesthetics in orkes gambus", Islam and Popular Culture in Indonesia and Malaysia edited by Andrew N. Weitraub. London: Routledge.

Hall, Stuart. 1997. Representation: Cultural Representation and Signifying Practices. London: Sage.

Hasan, N. (2009). The Making of Public Islam; Agency and Commodification on The Landscape of the Indonesian Public Sphre. Contemporary Islam, 245.

Heryanto, Ariel. Identitas dan Kenikmatan: Politik Budaya Layar Indonesia. Jakarta,: Gramedia, 2015.

Jati, Wasisto Raharjo, "Islam Populer sebagai Pencarian Identitas Muslim
Kelas Menengah Indonesia", Teosofi, Vol. 5, Nomor 1, Juni 2015, hal. 139-163.

Koentjaraningrat. (2009). Pengantar Ilmu Antropologi . Rineka Cipta: Jakarta.

M. Quraish Shihab. Jilbab Pakaian Wanita Muslimah; pandangan Ulama masa lalu dan cendikiawan kontemporer. Jakarta: Penerbit Lentera Hati. 2004.

Muhammad, A. (2018). Sabyan, islamic Music and Popular Culture. Jakarta: The Jakarta Post.

Muhammad, D. (2018). Sabyan Gambus; Popularity and Change. Jakarta: The Jakarta Post.

N, A. M., \& Zapin, M. (2004). Folk Dance of the Malay. Singapore: Oxford University Press.

Noorhaidi Hasan, "The Making of Public Islam; Piety, Agency and Commodification on the landscape of the Indonesian Public Sphere", Contemporary Islam, vol. 3 , no. 3 (2009) p. 245

Shihab, M. Q. (2004). Jilbab Pakaian Wanita Muslimah; Pandangan Ulama Masa Lalu dan Cendikiawan Kontemporer. Jakarta: Lentera Hati.

Syofyan, Donny. "Sabyan Gambus; Popularity and Change", The Jakarta Post, 9 Juli 2018. 